\title{
Megadose Methylprednisolone (MDMP) for Hemangiomatosis
}

\author{
Hemangiomatosis'in Metilprednizolon ile Tedavisi
}

\author{
Şinasi Özsoylu \\ Retired Prof of Pediatrics, Hematology, Hepatology, Ankara, Turkey \\ Honorary fellow of American Academy of Pediatrics \\ Honorary member of American Pediatric Society
}

\section{To the Editor,}

Dr. Küpeli and his colleagues[1] should be congratulated for their success in treating hemangiomatosis, which could be life threatining depending on the localization of hemangiomas, with propranolol. I prefer the term infantile hemangiomatosis instead of segmental hemangiomatosis[2] for the authors' patient. My primary reason in writing this letter is to clarify MDMP treatment, which caused severe cushingoid appearance in the patient prior to propranolol treatment.

In MDMP treatment the timing and duration of MP administration is extremely important; the daily dose must be administered at 0600, either orally or intravenously over the course of 10-15 min. To overcome the bitter taste of MP associated with oral administration, I recommend covering MP with honey. I have used MDMP at 30-100 $\mathrm{mg} / \mathrm{kg} / \mathrm{d}$ as a starting dose for different hematological and non-hematological conditions $[3,4]$ that were resistant or refractory to conventional corticosteroid treatment (1-2 $\mathrm{mg} / \mathrm{kg} / \mathrm{d}$ in divided doses) for several months-years, [3] including hemangiomas, infantile hemangiomatosis, and Kasabach-Merritt syndrome,[5] without observing severe cushingoid appearance. In addition, among 700 patients I observed no or only mild adverse effects of corticosteroids, as reported by others[6]. I have advocated ACTH-corticosteroid homeostasis during MDMP treatment, which differs from pulse MP (in which $1 \mathrm{~g}$ of MP is intravenously infused over the course of 3-4 h at any time of the d) and conventional corticosteroid administration (in divided doses).

MDMP is a type of corticosteroid treatment characterized by ACTH-corticosteroid homeostasis via administering the total daily dose (which starts at $30-100 \mathrm{mg} /$ $\mathrm{kg} / \mathrm{d}$ ) and gradual tapering[7]. With the exception of acute ITP, it is administered weeks, months, and years without marked adverse effects of steroids. I would like to question the timing and duration of MP administration in the authors' patient. MDMP was administered over the course of months in a patient with Kasabach-Merritt syndrome, with some increased doses in between which sternum was also involved[5]. MDMP and conventional corticosteroid treatment were comparatively studied by Uysal et al. for the treatment of hemangiomas, and it was observed that MDMP was superior[8]. Lastly, I would like to indicate that I used propranolol $2-5 \mathrm{mg} / \mathrm{kg}$ for the treatment of portal hypertension in children [9].

\section{References}

1. Küpeli S, Çimen D, Küpeli BY. Successful treatment with propronolol in a patient with a segmental hemangioma: A case report. Turk J Hematol 2012;29:170-173

2. Ozsoylu S. Mega dose methylprednisolone for diffuse infantile haemangiomatosis. Eur J Pediatr 1992; 151:389

3. Özsoylu Ş. High-dose methylprednisolone (HIVMP) in hematologic disorders. Hematology Reviews 1990;4:197207

\section{Address for Correspondence: Şinasi ÖZSOYLU, M.D., Beysukent Altınşehir Sitesi No:30, Ankara, Turkey \\ Phone: +903122354188 E-mail: sinasiozsoylu@hotmail.com}

Received/Geliş tarihi : July 12, 2012

Accepted/Kabul tarihi : July 12, 2012 
4. Özsoylu Ş. Megadose methylprednisolone for hematologic and non hematologic disorders. Turk J Hematol 2010; 27:130-131

5. Özsoylu Ş, İrken G, Gürgey A. High-dose intravenous methylprednisolone for Kasabach-Merritt syndrome. Eur J Pediatr 1989; 148:403-405

6. Bernini C, Carillo M, Buchanon GR. High-dose intravenous methylprednisolone therapy for patients with DiamondBlackfan anemia refractory to conventional doses of prednisolone. J Pediatr 1995; 127:654-659

7. Özsoylu Ş. How should corticosteroid be used? Turk Med Sci 2007; 37:123-124

8. Uysal KM, Olgun N, Erbay A, Sarıalioğlu F. High dose oral methylprednisolone therapy in childhood hemangiomas. Pediatr Hematol Oncol 2001; 18:335-341

9. Ozsoylu S, Koçak N, Yüce A. Propranolol treatment for portal hypertension in children. J Pediatr 1985; 106:317-321

\section{Reply}

\section{In response to "Megadose Methylprednisolone (MDMP) for Hemangiomatosis"}

We are grateful to Dr. Özsoylu for his valuable comments on our case report concerning the treatment of hemangiomatosis with propranolol [1]. One of the issues raised by Dr. Ozsoylu is regarding with the terminology used to describe hemangiomatous lesions. Although the term infantile hemangiomatosis could be used solely to describe the lesions in our patient, as Dr. Özsoylu pointed out, recent reports have frequently categorized hemangiomas as localized and segmental subtypes. Localized hemangiomas originate from a central focus, whereas segmental hemangiomas are clusters of hemangiomas with an extension corresponding to a recognizable or significant portion of a developmental segment, or involve a broad anatomic region of skin [2]. The segments in our patient with hemangiomas on the mandible, chin, bilateral preauricular region, neck, anterior region of the tongue, and left periorbital region approximate the mandibular and maxillary prominences described in medical embryology texts [3].

Systemic corticosteroids have been the mainstay of hemangioma treatment since the 1960s. Oral or intravenous MP and prednisone are effective for shrinking hemangiomatous lesions in infants. Cushingoid appearance and delayed healing of the cervical ulcerated lesion in our case were attributed to prolonged use of systemic MP. Recent studies have reported successful treatment of hemangiomas with the $\beta$-blocking agent propranolol, even in low birth weight infants $[4,5]$. Propranolol is now considered a first-line choice in many centers for the treatment of infantile hemangiomas and vasoconstriction; decreased expression of vascular endothelial growth factor and $\beta$-fibroblast growth factor genes, and triggering apoptosis in capillary endothelial cells are the proposed mechanisms of action.

Our patient had been treated initially with intravenous MP $30 \mathrm{mg} / \mathrm{kg} / \mathrm{d}$ at another hospital and after discharge the same dose was prescribed for daily divided administration. As a result, on admission to our hospital the patient had been taking MP $30 \mathrm{mg} / \mathrm{kg} / \mathrm{d}$ for 2 months. Unfortunately, our patient was treated with MDMP without respecting ACTH-corticosteroid homeostasis, the significance of which was emphasized by Dr. Özsoylu [6]. We are in absolute agreement with Dr. Özsoylu in that when treating with MDMP the timing and duration of administration of MP are extremely important; the daily dose must be administered at 0600 , either orally or intravenously over the course of 10-15 min.

\section{References}

1. Küpeli S, Çimen D, Yağcl-Küpeli B. Successful treatment with propronolol in a patient with a segmental hemangioma: A case report. Turk J Hematol 2012; 29: 170-173

2. Haggstrom AN, Lammer EJ, Schneider RA, Marcucio R, Frieden IJ. Patterns of infantile hemangiomas: New clues to hemangioma pathogenesis and embryonic facial development. Pediatrics 2006; 117: 698-703.

3. Larsen, WJ. Human Embryology. New York, NY: Churchill Livingstone; 1993: 321; 360-371

4. Küpeli S. Use of propranolol for infantile hemangiomas. Pediatr Hematol Oncol 2012; 29: 293-298

5. Erbay A, Sarialioglu F, Malbora B, Yildirim SV, Varan B, Tarcan A, Gülcan H, Demir S, Derbent M, Uslu N, Abbasoğlu A. Propranolol for infantile hemangiomas: a preliminary report on efficacy and safety in very low birth weight infants. Turk J Pediatr 2010; 52: 450-456

6. Özsoylu Ş. How should corticosteroid be used? Turk Med Sci 2007; 37: 123-124

Serhan Küpeli, M.D., M.Sc.

Derya Çimen, M.D.

Begül Yağcı-Küpeli, M.D., M.Sc. 